\title{
Incidence of Hepatitis $C$ virus infection in surgery patients of District Swat, Pakistan
}

\author{
Nasib Zaman ${ }^{1}$, Ubaid Ahmad ${ }^{1}$, Zafran Khan ${ }^{1,2 *}$, Daniya Ualiyeva ${ }^{2,3}$, Asaf \\ Khan $^{1}$, Muhammad Rizwan ${ }^{1}$, Shahzad Ahmad Khan ${ }^{1}$ and Shujait Ali ${ }^{1}$ \\ 1. Center for Biotechnology and Microbiology, University of Swat, Pakistan \\ 2. University of Chinese Academy of Sciences, Beijing, 100049, China \\ 3. Faculty of Biology and Biotechnology, Al-Farabi Kazakh National University, Almaty, 050040 Kazakhstan \\ *Corresponding author's email: zafrankhan807@yahoo.com \\ Citation \\ Nasib Zaman, Ubaid Ahmad, Zafran Khan, Daniya Ualiyeva, Asaf Khan, Muhammad Rizwan, Shahzad Ahmad Khan \\ and Shujait Ali. Incidence of Hepatitis $\mathrm{C}$ virus infection in surgery patients of District Swat, Pakistan. Pure and \\ Applied Biology. Vol. 11, Issue 2, pp553-560, http://dx.doi.org/10.19045/bspab.2022.110085
}

\begin{tabular}{llll}
\hline \hline Received: 23/08/2021 & Revised: 25/10/2021 & Accepted: 16/11/2021 & Online First: 20/11/2021 \\
\hline
\end{tabular}

\section{Abstract}

Hepatitis $\mathrm{C}$ virus (HCV) infection is predominantly recognized as a major public health concern in Pakistan. The prevalence of HCV infection and its major risk factors have been found out in different populations of various districts of Khyber Pakhtunkhwa (KPK), Pakistan. However, its incidence in surgery patients remains a mystery; thus, the current study aimed to investigate the incidence of HCV infection among the surgery patients in the district Swat. A total of 304 blood samples $(n=500)$ were collected from the different hospitals of district Swat, especially from Saidu Teaching Hospital, from April 2020 to September 2020. The blood samples were screened through HEALGEN SCIENTIC LLC strips for serological analysis of HCV antibodies. The average incidence of $\mathrm{HCV}$ in surgery patients was $6.6 \%$. While the incidence of $\mathrm{HCV}$ in surgery patients was higher in females $(8 \%)$ than in males $(6 \%)$. We also found that the rate of infection was high in the age group of more than 40 , which was $17 \%$, and least in the age group less than 40 years of age which was $3 \%$ (P-value $<0.191$, Odds ratio $(\mathrm{OR})=0.442$ ). Furthermore, the sero-incidence of hepatitis was higher in the blood transfused patients $13 \%$. Our results concluded a high incidence rate of HCV infection in the Swat region's surgery patients. To prevent the risk of high incidence, further research on a regional scale is recommended.

Keywords: Chronic hepatitis; Hepatitis C virus; Incidence; Risk-factors; Surgery

\section{Introduction}

Hepatitis $\mathrm{C}$ virus (HCV) is an RNA virus belonging to the Flaviviridae family, about 40-50 $\mathrm{nm}$ in diameter, an important pathogen for non-A and non-B parenteral hepatitis. While it was discovered by colleagues from the Choo and Chiron team in 1989 as a potential viral agent for non-A, non-B hepatitis [1-3]. Hepatitis is a remarkable public health challenge. Approximately, 200 million individuals are infected by the $\mathrm{HCV}$, constituting about $3.3 \%$ of the world population [4, 5]. Among them, 2 million cases of HCV were reported in Japan, 2.7 million were in the United States, 5 million were in Europe, and about 10 million were in Pakistan [6]. The country with the highest $\mathrm{HCV}$ prevalence rate is Egypt. Where infection rate steadily increases with age, and the infection rate is high among people of all age groups $[7,8]$. This pattern shows a high risk in the distant past and the subsequent 
ongoing high risk of acquiring HCV infection, though there are regional differences in average overall prevalence [7, 9]. Determining the incidence of $\mathrm{HCV}$ infection (i.e., the newly acquired infection rate) is difficult because most acute infections are asymptomatic, and the available testing methods cannot distinguish acute from chronic or resolved infections. In most countries/regions, there is no systematic collection of data on acute disease cases. Even in countries with well-developed surveillance systems, the acute disease reporting systems underestimate the incidence of $\mathrm{HCV}$ infection [10-12]. For some countries, mathematical models have been used to infer incidence trends based on the assumption that the current prevalence of a particular age reflects the cumulative risk of infection. Also, worldwide, $50 \%$ to $80 \%$ of people develop chronic infections [13], resulting in a large number of lives lost every year [14]. Chronic liver disease may develop for many years after infection, and the past morbidity is the main determinant of the future burden of $\mathrm{HCV}$ related complications [15]. In the United States and other countries/regions where $\mathrm{HCV}$ infection has recently occurred, the infection time of most infected people has not reached the time point when chronic liver disease complications usually occur [16, 17]. In countries where $\mathrm{HCV}$ infection has occurred in the distant past (such as Japan and Italy), the burden of HCV-related chronic diseases may have reached the greatest extent. However, changes in disease transmission methods have led to young people becoming infected with age, which may lead to an increase in chronic diseases [18].

According to a cohort study (a prospective study) and a case-control study (a retrospective study) of patients with acute diseases (or infections), risk factors related to infections include blood transfusion and blood transfusion, and solid organ transplantation from infected donors. Injecting drugs, unsafe therapeutic injections, occupational blood contact (mainly contaminated needle sticks), an infected mothers birth, and sex with an infected partner, and sex with multiple partners [19, 20]. Among them, the most important are the blood transfusions of unscreened donors, the use of injected drugs, and unsafe therapeutic injections. Although, the degree of influence of these risk factors on $\mathrm{HCV}$ transmission varies in time and geography.

However, the global epidemiological study of hepatitis A and B has been well established. However, little data are available about HCV in some regions of the world, predominantly in Pakistan. In Pakistan, where there has been an ongoing high risk for decades, the high magnitude of the current burden of $\mathrm{HCV}$ disease is predicted to continue into the future. Thus current study amid to determine the incidence of $\mathrm{HCV}$ in surgery patients in the northern area of Pakistan in district Swat and $\mathrm{HCV}$ infection-related risk factors.

\section{Materials and Methods Study area}

The samples were collected from various hospitals of Swat (Fig.1), specifically from Imperial Hospital, Saidu Teaching Hospital, Central Hospital, and SENA Medical Complex.

\section{Study duration}

The current study was conducted from April 2020 to September 2020.

Sample size: About three hundred and four patients were selected for the current study, including males and females.

\section{Selection criteria}

Patients of both genders were chosen, and the main selection criteria was a surgery patient.

\section{Collection of data}

Data collection was achieved by means of a questionnaire. A particular questionnaire was created and filled out by numerous surgical patients. The basic questions were related to their personal information, i.e., gender, age, 
marital status, education, blood transfusion, knowledge of HCV.

\section{Collection of blood sample}

About $5 \mathrm{ml}$ of blood was collected in an Ethylene Diamine Tetra Acetate (EDTA) tube for screening from each patient after the questionnaire session. For further processing, the sample was swiftly transferred to the laboratory of the Swat University, Center for Biotechnology and Microbiology.

\section{HCV antibody detection procedure}

The HEALGEN SCIENTIC LLC Cassette was used for the rapid $\mathrm{HCV}$ diagnosis. At first, blood taken from the patient was centrifuged for five minutes, and serum was isolated from blood. Then placed the cassette on a clean and level table. Hold the dropper vertically and transfer one drop of serum about 30 microliters, then we add one drop of 40 microliters of buffer quickly. After this, wait for the colored line for 15 minutes. When both $\mathrm{C}$ (control) and $\mathrm{T}$ (Test) lines appear in the kit, it indicates a positive result. When only the $\mathrm{C}$ line appears, it indicates a negative result. In case there was no $\mathrm{C}$ line developed, this will indicate an invalid result. Statistical analysis

All the statistical analysis was done with the help of Statistical Package for the Social Sciences (SPSS) software and an excel sheet.

\section{Ethical Consideration}

The ethical committee of Saidu Teaching Hospital Saidu Sharif Swat approved the current study, and each patient signed a consent letter before data collection.

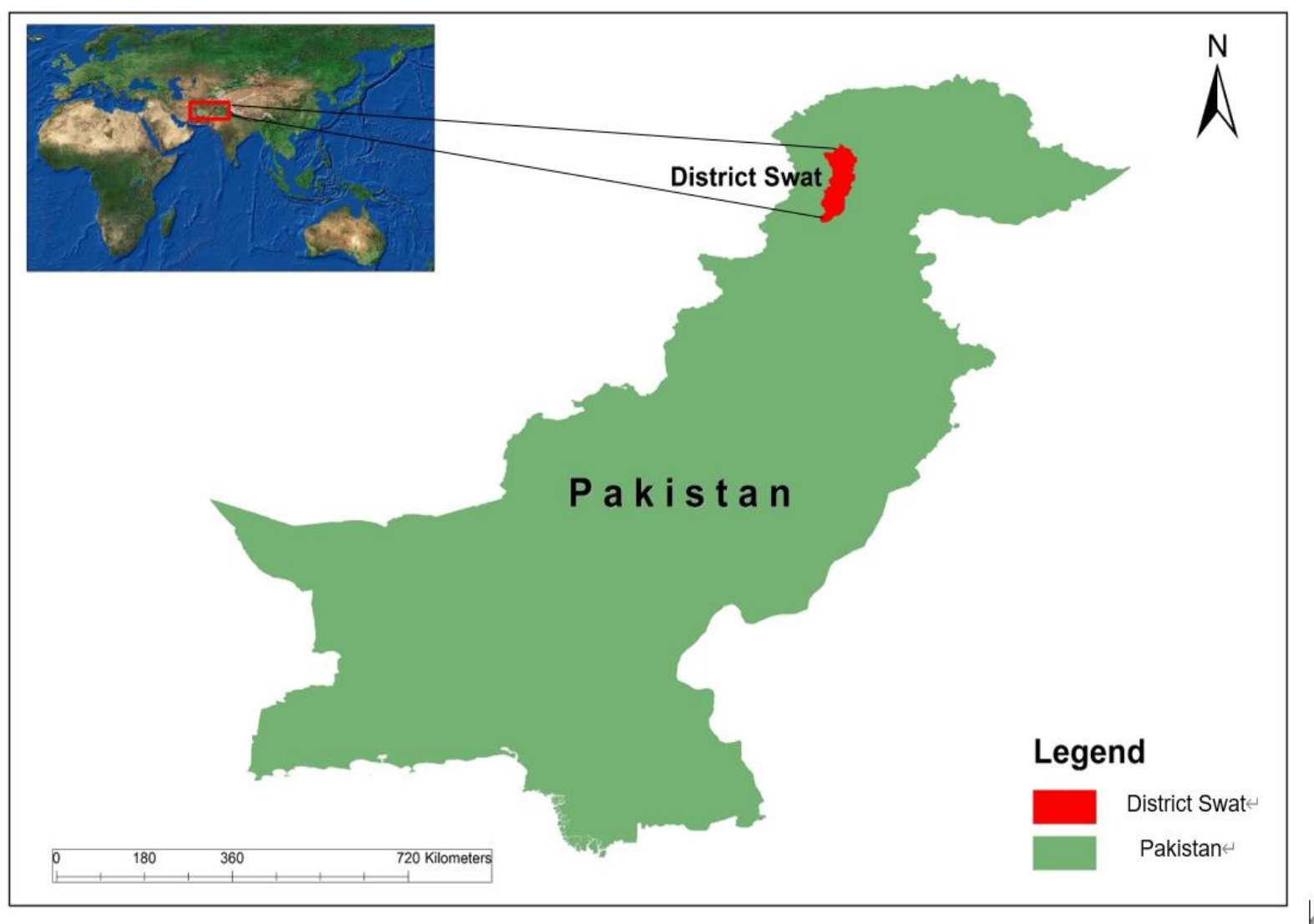

Figure 1. The district Swat, Pakistan 


\section{Results \\ HCV Infection and its association with gender}

The (Table 1) shows HCV infection and its association with gender. Three hundred four patients were selected for the study. Out of 304 patients, $204(66.6 \%)$ patients were male, and $100(33.4 \%)$ patients were female. In male patients, $12(6 \%)$ out of 204 were $\mathrm{HCV}$ positive, while $188(94 \%)$ were $\mathrm{HCV}$ negative. Similarly, $8(8 \%)$ were $\mathrm{HCV}$ positive in female patients, while $92(92 \%)$ were negative.

Table 1. HCV infection and its association with gender

\begin{tabular}{|c|c|c|c|c|c|c|}
\hline Age & Positive & Negative & Total & Chi-square & P-value & Odd ratio \\
More than 40 & $17(7.6 \%)$ & $217(92.4 \%)$ & 234 & $\mathbf{1 . 7 0 8}$ & $\mathbf{0 . 1 9 1}$ & $\mathbf{0 . 4 4 2}$ \\
\hline Less than 40 & $3(4.3 \%)$ & $67(95.7 \%)$ & 70 & & \\
\hline
\end{tabular}

HCV Infection and its association with age The (Table 2) shows HCV infection and its association with gender. Patients ages were noted in the study, and it was found that those patients whose ages were greater than 40 years were $234(76.6 \%)$ in number, among which $17(7.6 \%)$ patients were $\mathrm{HCV}$ positive while $217(92.4 \%)$ patients were $\mathrm{HCV}$ negative. Similarly, those patients whose ages were less than 40 years were $70(23.4 \%)$ in number, in which $3(4.3 \%)$ patients were HCV positive while 67(95.7\%) patients were negative. Patients ages ranged from 15 to 70 years were included in the study. The mean age of this study was 40 years.

Table 2. HCV infection and its association with age

\begin{tabular}{|c|c|c|c|c|c|c|}
\hline Gender & Positive & Negative & Total & \multirow{4}{*}{$\begin{array}{c}\text { Chi-square } \\
\mathbf{0 . 4 9 0}\end{array}$} & \multirow{4}{*}{$\begin{array}{c}P \text {-value } \\
0.484\end{array}$} & \multirow{4}{*}{$\begin{array}{c}\text { Odd ratio } \\
0.719\end{array}$} \\
\hline Male & $12(6 \%)$ & $192(94 \%)$ & 204 & & & \\
\hline Female & $8(8 \%)$ & $92(92 \%)$ & 100 & & & \\
\hline Total & $20(6.6 \%)$ & $284(93.4 \%)$ & 304 & & & \\
\hline
\end{tabular}

HCV Infection and its association with marital status

The (Table 3) shows HCV infection and its association with marital status. The marital information was also collected and included in the study, which shows that $259(85 \%)$ patients were married, of which 19(7.3\%) were $\mathrm{HCV}$ positive. $45(15 \%)$ patients were un-married, in which $1(2.2 \%)$ patient was positive.

Table 3. HCV infection and its association with marital status

\begin{tabular}{|c|c|c|c|c|c|c|}
\hline Marital Status & Positive & Negative & Total & \multirow{4}{*}{$\begin{array}{c}\text { Chi-Square } \\
1.631\end{array}$} & \multirow{4}{*}{$\begin{array}{c}P \text {-value } \\
0.202\end{array}$} & \multirow{4}{*}{$\begin{array}{c}\text { Odd ratio } \\
4.586\end{array}$} \\
\hline Married & $19(7.3 \%)$ & $240(92.7 \%)$ & 259 & & & \\
\hline Unmarried & $1(2.2 \%)$ & $44(97.7 \%)$ & 45 & & & \\
\hline Total & $20(10 \%)$ & $284(90 \%)$ & 304 & & & \\
\hline
\end{tabular}

Infection and its association with blood transfusion history

The (Table 4) shows HCV infection and its association with blood transfusion. In the present study, about 254(83.5\%) patients have a blood transfusion history, of which
13(5.2\%) were HCV positive, and 241(94.8\%) were HCV negative. Similarly, $50(16.5 \%)$ patients do not have any history of blood transfusion, in which $7(14 \%)$ patients were Hepatitis $\mathrm{C}$ virus (HCV) positive, and 43(86\%) were negative. 
Table 4. HCV infection and its association with blood transfusion

\begin{tabular}{|c|c|c|c|c|c|}
\hline HCV Status & $\begin{array}{c}\text { Transfusion } \\
\text { YES }\end{array}$ & $\begin{array}{c}\text { Transfusion } \\
\text { NO }\end{array}$ & \multirow{2}{*}{ Chi-square } & P-value & Odd ratio \\
HCV Positive & $13(5.2 \%)$ & $7(14 \%)$ & $\mathbf{5 . 3 6 2}$ & $\mathbf{0 . 0 2 1}$ & $\mathbf{3 . 0 1 8}$ \\
HCV Negative & $241(94.8 \%)$ & $43(86 \%)$ & & & \\
\hline Total & $\mathbf{2 5 4}$ & $\mathbf{5 0}$ & & \\
\hline
\end{tabular}

Awareness wise distribution of the patients have awareness while 20(6.6\%) have patients no awareness about HCV.

The (Table $5 \&$ Fig. 2) shows awareness of persons about HCV infection .284(93.4\%)

Table 5. HCV infection and its association with awareness

\begin{tabular}{|c|c|c|c|c|}
\hline $\begin{array}{c}\text { Awareness } \\
\text { YES }\end{array}$ & $\begin{array}{c}\text { Awareness } \\
\text { NO }\end{array}$ & $\begin{array}{c}\text { Chi square } \\
\mathbf{1 1 . 8 2 0}\end{array}$ & $\begin{array}{c}\text { P-value } \\
\mathbf{0 . 0 0 1}\end{array}$ & $\begin{array}{c}\text { Odd ratio } \\
\mathbf{0 . 1 6 7}\end{array}$ \\
\hline $284(93.4 \%)$ & $20(6.6 \%)$ & & \\
\hline
\end{tabular}

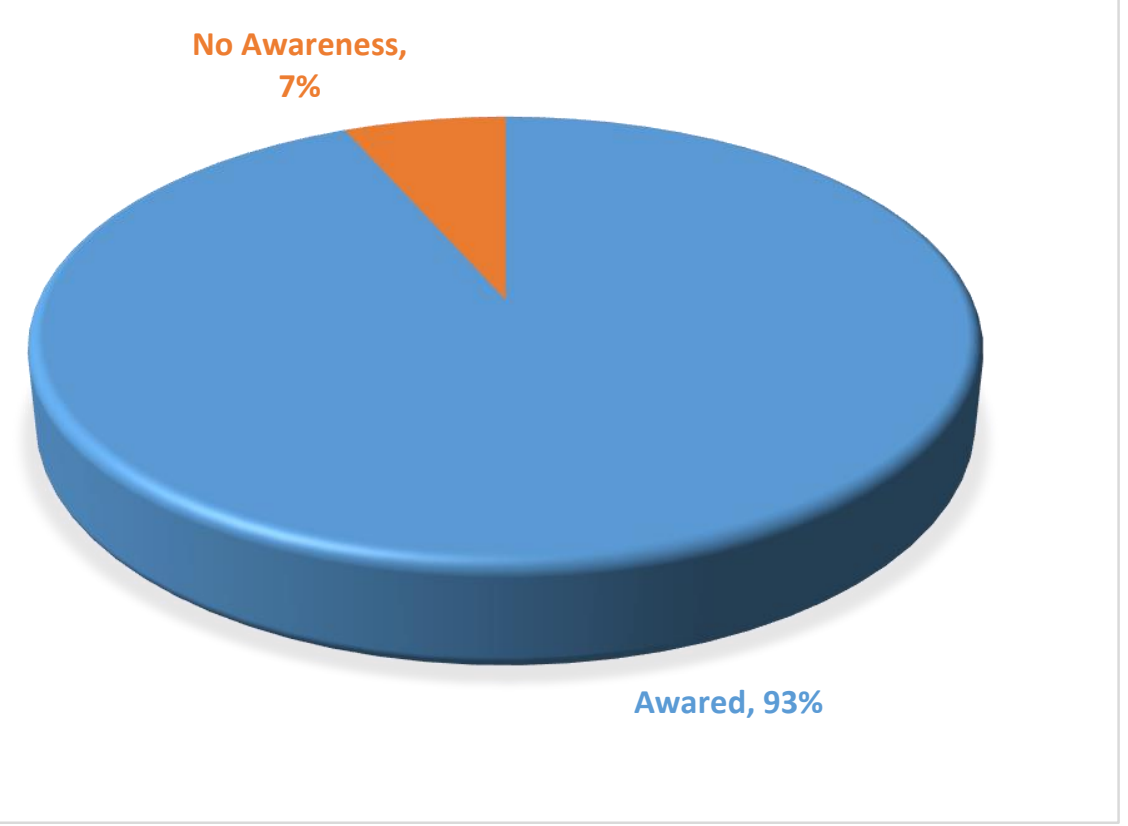

Figure 2. Hepatitis $\mathrm{C}$ virus (HCV) infection and its association with awareness

Educational wise distribution of selected patients

The (Table $6 \&$ Fig. 3) show the education level of selected persons in which 234
(76.6\%) patients were found illiterate and $70(23.4 \%)$ patients were literate out of 304.

Table 6. Educational wise distribution of the selected patients

\begin{tabular}{|c|c|c|c|c|c|}
\hline Illiterate & Percentage & literate & Percentage & Chi square & p- value \\
\hline 234 & $76.6 \%$ & 70 & $23.4 \%$ & 6.404 & 0.041 \\
\hline
\end{tabular}




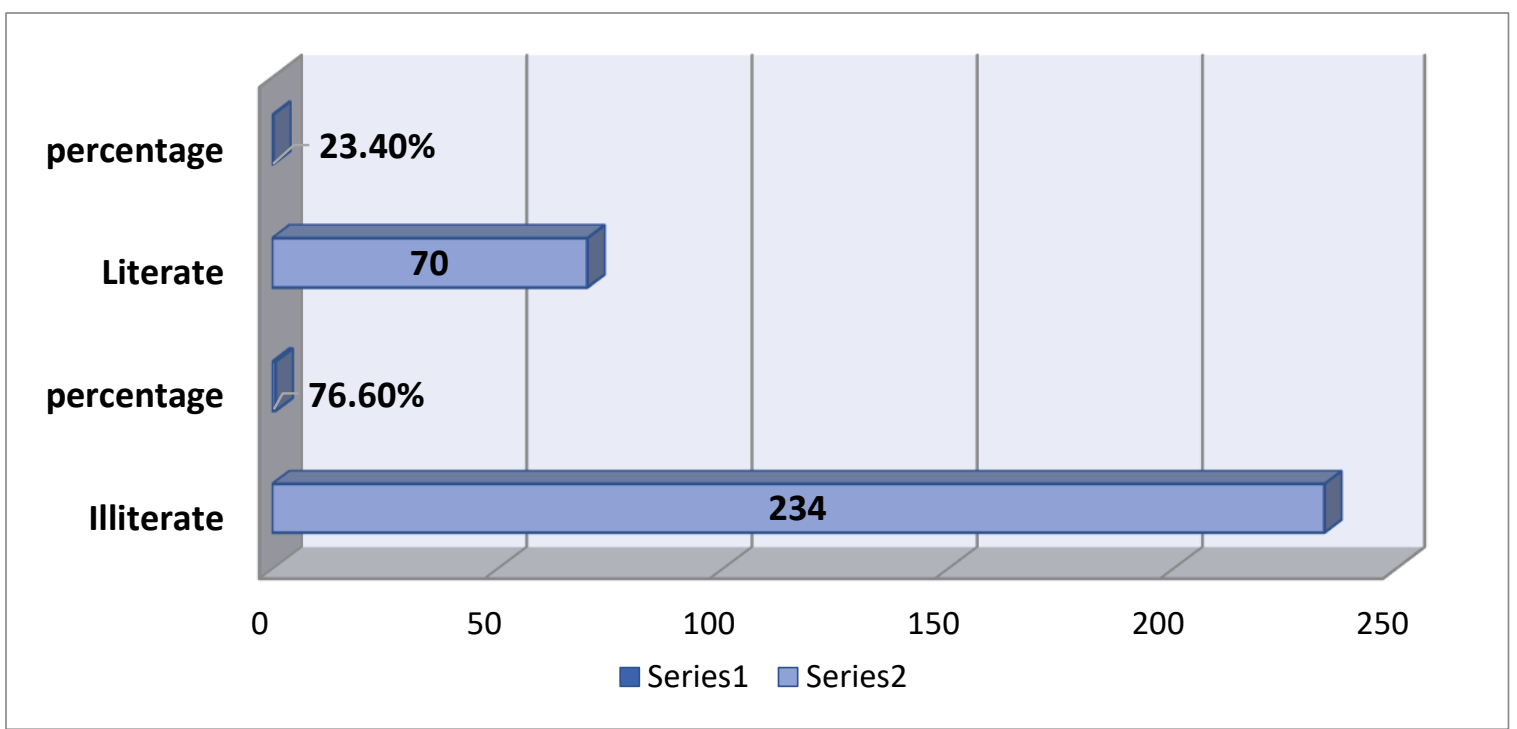

Figure 3. Education-wise distributions of the selected patients

\section{Discussion}

Hepatitis $\mathrm{C}$ is an infectious disease caused by $\mathrm{HCV}$ that was primarily affecting the liver. During the initial symptoms, people have mild or no symptoms at all, occasionally a fever, dark color urine, abdominal pain, and yellow tinged skin color [21-23]. According to many reports, blood-borne infections are increasing day by day, and there are many reasons behind it. However, one of the primary causes is unsterilized equipment used during surgery [24]. Dialysis centers are also the big cause of blood-borne infections such as $\mathrm{HCV}$. We investigated the incidence of $\mathrm{HCV}$ infection in patients to obtain some basic information and evaluate the assessments of infection control measures. The incidence of HCV infection is different in different countries of the world; the present study aimed to determine the incidence of HCV in surgery patients of district Swat. For this purpose, a total of 304 samples were examined for HCV infection. In the current study, most of the patients had acquired HCV infection by surgery. Many studies suggest that surgery is a high-risk factor for $\mathrm{HCV}$ transmission because of unsterilized equipment used for surgery or other medical procedures [25]. In the current study, the
$\mathrm{HCV}$ positive male was (12\%), and $\mathrm{HCV}$ positive female was (8\%). According to our data, the highest rate of infection was found in those people whose ages were ranges from (61 to 70); these results are in agreement with the previous study of High et al. [26], who reported that patients having ages (55 to 70) have the highest incidence of $\mathrm{HCV}$.

Moreover, we also found that the majority of positive patients in our data belonged to urban areas. These results were in line with the results reported by [27]. In our study, it has been reported that apart from surgery, there are a lot of other factors that can be associated with Hepatitis $C$ virus prevalence, such as blood transfusion from an infected individual to a healthy individual, dental procedure, low socioeconomic status, drug through an infected or unsterilized syringe. A similar study also reported from India that patients have a high prevalence of Hepatitis $C$ virus infection undergoing hemodialysis [28]. The current study has few confines. First, we could not collect samples from all surgery hospitals of district Swat; secondly, confirmatory techniques such as polymerase chain reaction (PCR) were not done in the present study.

\section{Conclusion}


The present study was conducted to find out the potential causes of $\mathrm{HCV}$ in patients who undergo some surgery. This study concluded that the potential causes of HCV infection in surgery patients are blood transfusion, unsterilized equipment, unsterilized beds, sheer ignorance of medical practitioners during surgery or any other medical procedure, etc. The current study recommends confirmation of $\mathrm{HCV}$ RNA using Real-Time Polymerase Chain Reaction (Rt PCR) and genotyping method. Our study also recommends $\mathrm{HCV}$ sequencing and mutational analysis for the antiviral therapy response.

\section{Authors' contributions}

Conceived and designed the experiments: $\mathrm{N}$ Zaman \& Z Khan, Performed the experiments: N Zaman, U Ahmad,A Khan \& M Rizwan, Analyzed the data: Z Khan, D Ualiyeva, SA Khan \& S Ali, Contributed materials/ analysis/ tools: S Ali, N Zaman, M Rizwan \& SA Khan, Wrote the paper: U Ahmad, Z Khan, A Khan \& N Zaman.

\section{References}

1. Choo QL, Kuo G, Weiner AJ, Overby LR, Bradly DW \& Houghton M (1989). Isolation of a cDNA clone derived from a bloodborne non-A, non-B viral hepatitis genome. Sci 244: 359-362.

2. Muhammad N \& Jan MA (2005). Frequency of hepatitis " $\mathrm{C}$ " in Buner, NWFP. J Coll Physicians Surg Pak 15: 11-4.

3. Khan Z (2017). Incidence of HCV in general population of District Swat, Pakistan. J of Antivirals \& Antiretrovirals 09(03).

4. Lausanne, Clinical Update-Debio 025 in Hepatitis C (2009) Available from: URL: http://www.debiopharm.com/pressreleases/debio-025/clinicalupdate-debio025-in-hepatitis-c.html

5. Khan $\mathrm{Z}$ et al., (2021). Incidence of Hepatitis $\mathrm{C}$ virus infection in Swat
District, Pakistan: a preliminary study. Pure and Appl Biol 11(1).

6. Hamid S, Umar M, Alam A, Siddiqui A, Qureshi H \& Butt J (2003). Pakistan Society of Gastroenterology. PSG consensus statement on management of hepatitis C virus infection. J Pak Med Assoc 54: 146-150.

7. Perz JF, Armstrong GL, Farrington LA, Hutin YJ \& Bell BP (2006). The contributions of hepatitis $\mathrm{B}$ virus and hepatitis $\mathrm{C}$ virus infections to cirrhosis and primary liver cancer worldwide. $J$ Hepatol 45: 529-538.

8. Abdel-Aziz F, Habib M, Mohamed MK, Abdel-Hamid M, Gamil F, Madkour S, Mikhail NN, Thomas D, Fix AD \& Strickland GT et al. (2000). Hepatitis C virus (HCV) infection in a community in the Nile Delta: population description and HCV prevalence. Hepatol 32: 111-115.

9. Medhat A, Shehata M, Magder LS, Mikhail N, Abdel-Baki L, Nafeh M, Abdel-Hamid M, Strickland GT, Fix AD (2002). Hepatitis c in a community in Upper Egypt: risk factors for infection. Am J Trop Med Hyg 66: 633-638.

10. Hagan H, Snyder N, Hough E, Yu T, McKeirnan S, Boase J \& Duchin J (2002). Case-reporting of acute hepatitis B and C among injection drug users. J Urban Health 79: 579-585.

11. Robotin MC, Copland J, Tallis G, Coleman D, Giele C, Carter L, Spencer J, Kaldor JM, Dore GJ (2004). Surveillance for newly acquired hepatitis $\mathrm{C}$ in Australia. J Gastroenterol Hepatol 19: 283-288.

12. Spada E, Mele A, Ciccozzi M, Tosti ME, Bianco E, Szklo A, Ragni P, Gallo G, Balocchini E \& Sangalli M et al. (2001). Changing epidemiology of parenterally transmitted viral hepatitis: results from the hepatitis surveillance system in Italy. Dig Liver Dis 33: 778-784. 
13. Centers for Disease Control and Prevention Recommendations for prevention and control of hepatitis $\mathrm{C}$ virus (HCV) infection and $\mathrm{HCV}$ related chronic disease (1998). MMWR Recomm Rep 47: 1-39.

14. Lo Re V \& Kostman JR (2005). Management of chronic hepatitis $\mathrm{C}$. Postgrad Med J 81: 376-82.

15. Perz JF, Alter MJ (2006). The coming wave of $\mathrm{HCV}$-related liver disease: dilemmas and challenges. J Hepatol 44: 441-443.

16. Armstrong GL, Alter MJ, McQuillan GM, Margolis HS (2000). The past incidence of hepatitis $\mathrm{C}$ virus infection: implications for the future burden of chronic liver disease in the United States. Hepatol 31: 777-782.

17. Deuffic S, Buffat L, Poynard T, Valleron AJ (1999). Modeling the hepatitis C virus epidemic in France. Hepatol 29: 15961601.

18. Deuffic S, Poynard T, Valleron AJ (1999). Correlation between hepatitis $\mathrm{C}$ virus prevalence and hepatocellular carcinoma mortality in Europe. J Viral Hepat 6: 411-413.

19. Alter MJ (2002). Prevention of spread of hepatitis C. Hepatol 36: S93-S98.

20. Recommendations for prevention and control of hepatitis $\mathrm{C}$ virus (HCV) infection and HCV-related chronic disease (1998). Centers for Disease Control and Prevention. MMWR Recomm Rep 47: 1-39.

21. Barrett S, Goh J, Coughlan B, Ryan E, Stewart S, Cockram AEA, O'keane JC \& Crowe J (2001). The natural course of hepatitis $\mathrm{C}$ virus infection after 22 years in a unique homogenous cohort: spontaneous viral clearance and chronic HCV infection. Gut 49(3): 423-430.

22. Musialik J, Suchecka W, KlimackaNawrot E, Petelenz M, Hartman M \&
Blonska-Fajfrowska B (2012). Taste and appetite disorders of chronic hepatitis $\mathrm{C}$ patients. Eur J of Gastroenterol \& Hepatol 24(12): 1400-1405.

23. El-Kamary SS, Shardell MD, AbdelHamid M, Ismail S, El-Ateek M, Metwally M, Mikhail N, Hashem M, Mousa A, Aboul-Fotouh A \& El-Kassas M (2009). A randomized controlled trial to assess the safety and efficacy of silymarin on symptoms, signs and biomarkers of acute hepatitis. Phytomedicine 16(5): 391-400.

24. Wand H, Spiegelman D, Law M, Jalaludin B, Kaldor J \& Maher L (2009). Estimating population attributable risk for hepatitis $\mathrm{C}$ seroconversion in injecting drug users in Australia: implications for prevention policy and planning. Addiction 104(12): 2049-2056.

25. Apostolou A, Bartholomew ML, Greeley R, Guilfoyle SM, Gordon M, Genese C, Davis JP, Montana B \& Borlaug G (2015). Transmission of hepatitis $\mathrm{C}$ virus associated with surgical proceduresNew Jersey 2010 and Wisconsin 2011. MMWR. Morbidity and Mortality Weekly Rep 64(7): 165.

26. High KP, Marcus EL \& Tur-Kaspa R (2005). Chronic hepatitis $\mathrm{C}$ virus infection in older adults. Cli Inf Dis 41(11): 1606-1612.

27. Aziz S, Khanani R, Noorulain W \& Rajper J (2010). Frequency of hepatitis B and $\mathrm{C}$ in rural and periurban Sindh. JPMA-J of the Pak Med Assoc 60(10): 853.

28. Malhotra R, Soin D, Grover P, Galhotra S, Khutan H \& Kaur N (2016). Hepatitis $B$ virus and hepatitis $C$ virus co-infection in hemodialysis patients: A retrospective study from a tertiary care hospital of North India. J of Nat Sci, Biol, and Med 7(1): 72 . 